\title{
ASPIDISTRA RENATAE (RUSCACEAE), A NEW SPECIES FROM CENTRAL VIETNAM
}

\author{
C. BRÄUCHLER ${ }^{1} \&$ L.H. NGOC ${ }^{2}$
}

\begin{abstract}
SUMMARY
Aspidistra renatae C. Bräuchler from Central Vietnam is described as a new species characterised by narrowly elliptic to linear petiolate leaves and campanulate flowers with a subglobose tube. Details on the type locality, association and ecology of the species are provided.
\end{abstract}

Key words: Convallariaceae, Ruscaceae, Aspidistra, Vietnam.

\section{INTRODUCTION}

The species was discovered by the first author on a joint expedition of the Institut für Organische Chemie Würzburg and the Institute of Industrial Chemistry Hanoi to Quangnam-Danang Province, Central Vietnam. One flowering individual was collected and recognised as a new species with respect to a revision of the Vietnamese species of Aspidistra (Tillich, 2005). The genus seems to be very diverse in Vietnam and Southern China (Tillich, 2005) with the highest number of species probably found at altitudes of 900-1000 m (Averyanov, pers. comm.).

\section{Aspidistra renatae C. Bräuchler, spec. nov. - Fig. 1}

Species A. atroviolacea Tillich similis sed differt foliis linearibus ad anguste ellipticis, nervis secundariis anastomosis tenuibus aequaliter distantibus coniunctis. - Typus: Bräuchler 3000 (holo M, including one dissected flower in the liquid collection labelled Braeuchler 186/39; iso MSB), Vietnam, Quangnam-Danang Province, Hoa Vang district, understorey of dense, slightly disturbed seasonal rain forest on steep granite slope, c. $700 \mathrm{~m}$, 23 April 2004.

Herbs perennial, evergreen, rhizomatous. Rhizome creeping, mostly subterrestrial, 3-9 mm diam., densely covered with scales. Roots thin ( $<1 \mathrm{~mm}$ diam.), moderately branched, emerging from the rhizome and spreading mostly horizontally to all sides. Leaves uniformly green, solitary, quite dense, leaf at tip of rhizome embraced by a sheath of 2 or 3 purple cataphylls (lower ones $2.1-4.2 \mathrm{~cm}$, upper one $9-11.5 \mathrm{~cm}$ ), getting brown and finally fibrous with further growth of rhizome; petioles $6-26 \mathrm{~cm}$; lamina narrowly elliptic to linear, $18-33$ by $1.2-2 \mathrm{~cm}$, midvein forming an abaxial prominent keel about $1 \mathrm{~mm}$ in height, $3-5$ prominent secondary longitudinal veins visible on both

1) LMU München, Department Biologie I, Biodiversitätsforschung - Systematische Botanik, Menzingerstr. 67, 80638 München, Germany; e-mail: braeuchler@1rz.uni-muenchen.de.

2) Institute of Industrial Chemistry, Department of Phytochemistry, 2 Pham Ngu Lao, Hanoi, Vietnam. 

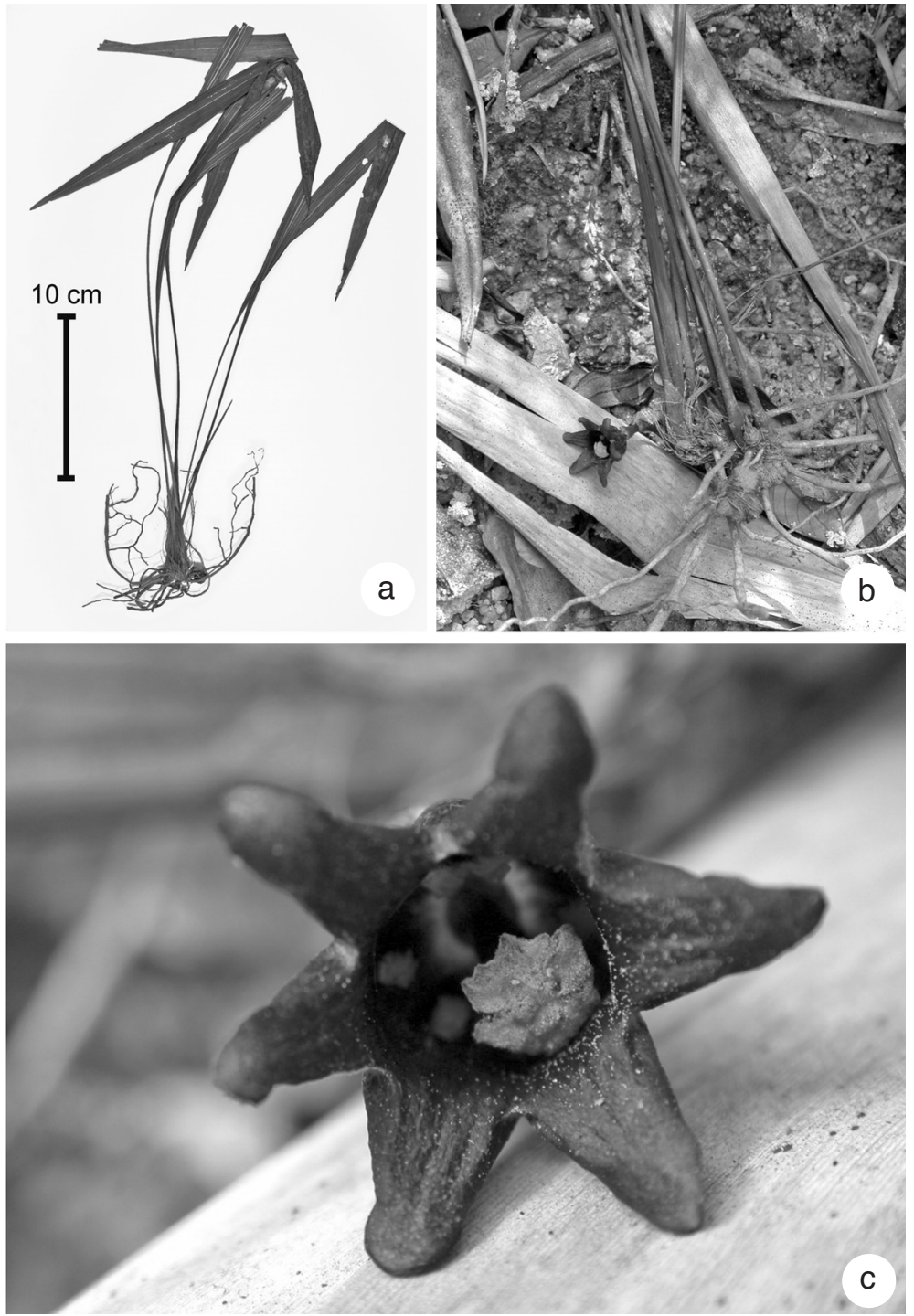

Fig. 1. Aspidistra renatae C. Bräuchler. a. Habitus of the holotype (picture of the dried specimen); b. flowering individual photographed at the type locality after collecting; c. flower close-up revealing a ring of non-pigmented tissue around the base of the ovary.

sides, connected more or less regularly every $5-7 \mathrm{~mm}$ by thin anastomoses, marginal vein absent. Flower solitary. Peduncle decumbent, c. $3 \mathrm{~cm}$ long, with 4 equidistantly alternating dark purplish violet bracts. Perigone campanulate with subglobose tube, dark purplish violet, not pigmented around base of gynoecium, tube wall up to $1 \mathrm{~mm}$ thick, tube 10 by $10 \mathrm{~mm}$ ( $9 \mathrm{~mm}$ wide at throat), lobes 6 , triangular, 7 by $5 \mathrm{~mm}$, moderately bent outwards $\left(25-30^{\circ}\right)$, constricted $3 \mathrm{~mm}$ from distal end, resulting in lobe ends appearing roundly. Stamens 6 , very small (c. 1.5 by $1.5 \mathrm{~mm}$ ), subsessile, inserted c. $3 \mathrm{~mm}$ 
above base, pollen and anthers bright yellowish in colour. Pistil c. $10 \mathrm{~mm}$ long and $1.9 \mathrm{~mm}$ diam. at thinnest point, ovary inconspicuous, $2.5 \mathrm{~mm}$ diam., style cylindrical, slender, stigma rounded hexagonal, with 6 shallow marginal incisions, surface slightly convex, 4-5 mm diam., white to pale purplish violet. Fruit unknown.

Distribution - Central Vietnam, Quangnam-Danang Province.

Notes -1 . This species is known only from the type locality, a seasonal rain forest on an E slope, where it grows on the dark forest floor on poor soil over granite in association with e.g. Adiantum, Hedyotis, Hymenophyllum, Ophiopogon, Phyllagathis and Rattan palms. The holotype was the only plant found flowering in a rich population (>30 individuals). Several plants are in cultivation at the Botanischer Garten München, Germany.

2. Etymology: Aspidistra renatae is named in memory and honour of the first author's mother Renate Bräuchler who died of cancer long before her time. All her life she loved plants, especially lilies of the valley, which used to give their scientific name to the family Aspidistra belonging to the Convallariaceae (Ruscaceae sensu APG II, 2003).

3. Phenology: Flowering season probably starts at the end of April, as also the Ophiopogon species started budding at the collecting site.

4. Pollination: Nothing is known concisely about the pollination of this species; however, the flowers are oriented horizontally (maybe also a bit downwards) lying on the substrate and are probably visited by small ground insects. At the collecting time (11 a.m.) no floral scent was recognised. The bright stigma is in high contrast to the dark surrounding and might serve as a first attraction point favouring pollination by arriving insects. A ring of non-pigmented tissue around the base of the gynoecium may serve as a light trap guiding the flower-visiting insects towards the proximate part of the flower, forcing them to pass the anthers.

5. Relationship: The closest ally may be Aspidistra atroviolacea Tillich from Bach Ma National Park. More distant morphological affinities exist towards A. retusa K.Y. Lang \& S.Z. Huang and A. triloba F. T. Wang \& K. Y. Lang (Lang, 1981). A key to the species is provided in Tillich (2005).

\section{ACKNOWLEDGEMENTS}

The authors would like to thank the following people and institutions: Prof. Dr. H.-J. Tillich and Dr. J. Bogner for their advice on Aspidistra, the Botanischer Garten München and staff, Prof. Dr. G. Heubl and Prof. Dr. G. Bringmann, for making the field trip possible in scheme of the DFG projects HE-2671/2 and BR-699/7, Prof. Dr. D. Podlech for help with the Latin diagnosis, Dr. M. Dreyer for photographs and company, Dr. J. Regalado and Dr. L. Averyanov for kind support and helpful discussions in Hanoi and finally Quang Le Dang (Department of Phytochemistry-IIC, Institute of Industrial Chemistry, Hanoi) for his help on our field trip.

\section{REFERENCES}

APG II. 2003. An update of the Angiosperm Phylogeny Group classification for the orders and families of flowering plants: APG II. Bot. J. Linn. Soc. 141: 399-436.

Lang, K. Y. 1981. New taxa of the genus Aspidistra from China. Acta Phytotax. Sin. 19: 379-385.

Tillich, H.-J. 2005. A key for Aspidistra (Ruscaceae), including 15 new species from Vietnam. Feddes Repert. Spec. Nov. 116, 5-6: 313-338. 